\title{
Physicochemical and functional characteristics of residual pulp of potato
}

\author{
Webber Tavares de CARVALHO ${ }^{1}$, Manoel Soares SOARES JÚNIOR ${ }^{1}$, Márcio CALIARI ${ }^{1 \star}$, Flávio Alves da SILVA ${ }^{1}$, \\ Keyla de Oliveira RIBEIRO ${ }^{1}$
}

\begin{abstract}
Starch-rich liquid effluent is generated after peeling, cutting and washing of tubers during the fries processing. After sedimentation of this effluent is recovered a wet residual pulp, and after drying is obtained dry residual pulp or simply named in this study residual pulp of potato (RPP). In order to convert the effluent into a material easy to store for long periods (such as the potato starch), which would make it suitable for various applications. The aim of this study was to evaluate the effect of the drying conditions, specifically variables temperature and air flow on the drying time and water activity, $\mathrm{pH}$, titratable acidity, instrumental colour parameters, water absorption index, water solubility index and oil absorption capacity of dry RPP. Central Composite Design was used, with temperature levels from 50.0 to $70.0{ }^{\circ} \mathrm{C}$ and air flow from 0.06 to $0.092 \mathrm{~m}^{3} \mathrm{~m}^{-2} \mathrm{~s}^{-1}$. Temperature and airflow affected the study characteristics, except for lightness $\left(L^{*}\right)$, water solubility index and oil absorption capacity. It was concluded that milder conditions (lower temperatures) and intermediate air flow resulted in higher-quality final products (lighter, less acidic), although requiring higher drying time. Therefore, depending on the product application, different drying conditions can be used.
\end{abstract}

Keywords: Solanum tuberosum L.; fries processing; effluent recover; drying; byproduct.

Practical Application: This product is a technological innovation in providing raw ingredient for use in the food industry.

\section{Introduction}

The generation of industrial effluent is a major problem for food industries (Wang et al., 2009). The fries industry generates after peeling, cutting and washing of tubers a highly polluting effluent rich in organic compounds, which if indiscriminately released as effluent in rivers and soil, which can cause serious environmental problems (Dias et al., 2013). The use of residual pulp of potato (RPP) in the generation of a stable product and its subsequent use as an ingredient of food product, as gluten-free spaghetti (Bastos et al., 2016), gluten-free biscuits (Batista et al., 2016) and fries snacks (Dias et al., 2014), can bring benefits, making it a product with added value, able to be used in other supply chains. In addition to the economic benefits, positive environmental factors may result from this measure, since this effluent would no longer be disposed into the environment, or at least the amount of effluent would be considerably reduced. A strategy for using this effluent from fries processing would be to convert it into a modified dry form, which could be stored as potato starch, suitable for various applications.

The conditions imposed to products during drying are of paramount significance in relation to their final quality. Factors such as temperature and airflow can significantly alter their characteristic. The application of high temperatures generally increases the drying rate, since it increases the ability to transport moisture (Carvalho et al., 2014). Although the increase in temperature positively responds to the increase in the drying rate, high temperatures may cause injuries to the product.
Re-hydration rate, colour and antioxidant activity decreased at high process temperature because cell disruption occurs at high air temperature (Vega-Gálvez et al., 2012). The drying air speed is important in removing the water vapor in the environment around the product, avoiding air saturation and resulting in a pressure differential of water vapor between the environment and the product surface, which favors the transfer of mass from solid to air (Silva et al., 2006).

The knowledge on the functional properties of food ingredients are key to verify their potential for food applications since these factors are related to the ability of products to absorb or dissolve in water at room temperature or heated, oil absorption during frying, among others.

Therefore, the objective of this study was to evaluate the influence of temperature and air flow on the drying time and on characteristics such as water activity, $\mathrm{pH}$, titratable acidity, instrumental colour parameters, water absorption index, water solubility index and oil absorption capacity in order to evaluate the final quality of RPP as an ingredient for food product formulations.

\section{Material and methods}

The effluent obtained in fries processing (cv. Atlantic) was collected between January and February 2012, in the Cicopal Company, located in the municipality of Senador Canedo, Goias, 
Brazil. This effluent was characterized as the water discharged during the washing of potatoes after peeling and cutting. The collection of effluent was held at the end of the pipe that comes out from the potato washing tank in a polypropylene container $(50 \mathrm{~L})$ and transported to laboratory. Before phase separation, the effluent was manually homogenized, and $1 \mathrm{~L}$ of sample was placed in a beaker during $15 \mathrm{~min}$ (optimized time previously) aiming the sedimentation of the starch. It was decided not to use cooling during the previous steps aiming at simulating the processing conditions, after which, the supernatant portion removed and the sediment portion was taken for drying to achieve moisture

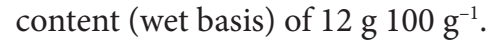

The drying trial followed a rotational central composite design with a full $2^{2}$ factorial, 4 axial points and 4 replicates at the central point, totaling 12 experiments, where independent variables were temperature $\left(\mathrm{x}_{1}\right)$ and airflow $\left(\mathrm{x}_{2}\right)$ (Table 1). Drying time was determined. Weighing of trays, initially containing $1 \mathrm{~kg}$ of wet RPP (dry basis), was made at intervals of 5 on 5 min until reaching $60 \mathrm{~min}$ of process, then at intervals of 10 to $10 \mathrm{~min}$ until reaching $130 \mathrm{~min}$ and thereafter at intervals of 20 to $20 \mathrm{~min}$. The dried material was stored in threaded polypropylene (PP) containers, sealed with polyvinyl chloride film (PVC), and stored at $-18^{\circ} \mathrm{C}$.

Water absorption index (WAI) and water solubility index (WSI) were obtained according to method described by Anderson et al. (1969). The oil absorption capacity (OAC) was estimated using the methodology of Castilho et al. (2010), where $2.0 \mathrm{~g}$ of the sample were homogenized in $10 \mathrm{ml}$ of soybean oil in a centrifuge tube for $2 \mathrm{~min}$. The water activity was assessed in portable water activity meter (Aqualab, CX-2 Decagon, Washington, USA). The $\mathrm{pH}$ of samples was determined according to method of Association of Official Analytical Chemists (2012). The titratable acidity was determined according to method of Adolfo Lutz Institute (Instituto Adolfo Lutz, 2008). The instrumental colour parameters were determined according to method described by Paucar-Menacho et al. (2008), using Colorquest colorimeter (Color Quest XE, Reston, U.S.), according to the CIELab system. Analyses were performed in triplicate.
Analysis of variance (ANOVA) was performed and the significance level used in the study was $5 \%$. The linear and quadratic effects and the interaction of each variable were assessed, as well as the lack of fit in the models. The mean data from each of the 12 experiments for each response were treated by multiple regression analysis to develop mathematical models containing linear and quadratic terms and the interaction of two independent variables. The non-significant terms of models were removed.

From the significant adjusted mathematical models $(\mathrm{p} \leq 0.05)$ and using the function Response Desirability Profiling of the e Statistica Software (StatSoft, version 7, Tulsa, USA), the most desirable RPP was determined, as function of temperature and air flow used. The most desirable RPP was considered the one with the highest $\mathrm{pH}$, and lowest chroma $\mathrm{a}^{\star}$, chroma $\mathrm{b}^{*}$ and titratable acidity values, so that the RPP least possible influence on the taste and colour of the formulated product with the same. The proximal composition (dry basis) and energetic value of RPP selected on the desirability test was determined according to Association of Official Analytical Chemists (2012). The analyses were performed in triplicate in samples submitted to drying at temperature of $60^{\circ} \mathrm{C}$ and air flow of $0.076 \mathrm{~m}^{3} \mathrm{~m}^{-2} \mathrm{~s}^{-1}$.

\section{Results and discussion}

From the data obtained (Table 1), all models were significant $(\mathrm{p} \leq 0.05)$, and showed no significant lack of fit $(\mathrm{p}>0.05)$, except for $\mathrm{pH}$ and WAI (Table 2). However, according to Waszczynskyj et al. (1981), whether the mean square for the experimental error presents low value, significance tests for lack of fit have to be deemed irrelevant, in this way, all the models can be used for predictive purposes.

The drying time ranged from 200 to $390 \mathrm{~min}$, with percentage variation of $95 \%$, which is strongly dependent on temperature. The airflow also affected the drying time, but to a lesser extent (Figure 1A). With the experimental design adopted, it was possible to observe a region of minimal drying time, which occurred at higher temperatures and for any airflow within the range studied.

Table 1. Drying time, water activitiy (Aw), $\mathrm{pH}$, acidity, chroma $\mathrm{a}^{\star}$, chroma $\mathrm{b}^{\star}$ and water absorption index (WAI) as a function temperature and air flow.

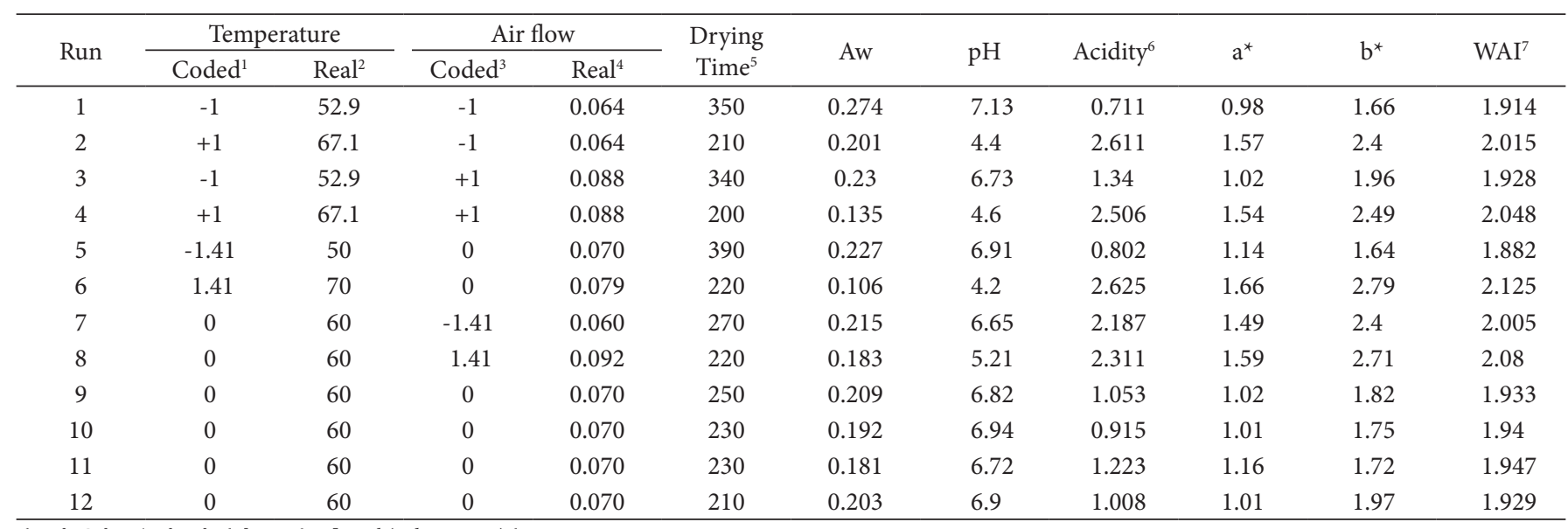

${ }^{1} \mathrm{x}_{1} ;{ }^{\circ} \mathrm{C} ;{ }^{3} \mathrm{x}_{2} ;{ }^{4} \mathrm{~m}^{3} \mathrm{~m}^{-2} \mathrm{~s}^{-1} ;{ }^{5} \mathrm{~min} ;{ }^{6} \% ;{ }^{7} \mathrm{~g}$ gel $(\mathrm{g} \text { dry matter })^{-1}$. 
Table 2. Significance levels (p) of temperature (x1) and air flow (x2) on drying time (DT), water activity (Aw), pH, titratable acidit (TA), chroma $\mathrm{a}^{\star}$ and chroma $\mathrm{b}^{\star}$, and water absorption index (WAI) of residual pulps of potato, adjusted regression models, determination coefficient $\left(\mathrm{R}^{2}\right)$ and lack of fit (LF).

\begin{tabular}{|c|c|c|c|c|c|c|c|c|}
\hline \multirow{2}{*}{ Factor } & \multicolumn{5}{|c|}{ Significance level (p) } & \multirow{2}{*}{ Adjusted regression model } & \multirow{2}{*}{$\mathrm{R}^{2}$} & \multirow{2}{*}{ LF } \\
\hline & $\mathrm{x}_{1}$ & $\mathrm{x}_{1}^{2}$ & $\mathrm{x}_{2}$ & $\mathrm{x}_{2}^{2}$ & $\mathrm{x}_{1} \mathrm{x}_{2}$ & & & \\
\hline DT & 0.01 & 0.01 & 0.02 & n.s. & n.s. & $y=236.0-68.2 x_{1}+36.2 x_{1}^{2}-11.4 x_{2}$ & 96.3 & 0.69 \\
\hline Aw & 0.01 & n.s. & 0.02 & n.s. & n.s. & $y=0.2-0.04 x_{1}-0.02 x_{2}$ & 82.7 & 0.17 \\
\hline $\mathrm{pH}$ & 0.01 & 0.01 & 0.04 & 0.01 & n.s & $y=6.85-1.09 x_{1}-0.65 x_{1}^{2}-0.28 x_{2}-0.47 x_{2}^{2}$ & 95.3 & 0.02 \\
\hline $\mathrm{TA}$ & 0.01 & 0.01 & n.s. & 0.01 & n.s & $y=1.05+0.71 x_{1}+0.28 x_{1}^{2}+0.55 x_{2}^{2}$ & 94.4 & 0.15 \\
\hline$a^{*}$ & 0.01 & 0.03 & n.s. & 0.01 & n.s. & $y=1.05+0.02 x_{1}+0.13 x_{1}^{2}+0.20 x_{2}^{2}$ & 86.3 & 0.16 \\
\hline$b^{*}$ & 0.01 & n.s & n.s. & 0.01 & n.s. & $y=1.92+0.36 x_{1}+0.28 x_{2}^{2}$ & 80.0 & 0.11 \\
\hline WAI & 0.01 & n.s. & n.s. & 0.02 & n.s. & $\mathrm{y}=1.95+0.07 \mathrm{x}_{1}+0.04 \mathrm{x}_{2}^{2}$ & 79.1 & 0.01 \\
\hline
\end{tabular}

n.s.: not significative $(\mathrm{p}>0.05)$.

(4)

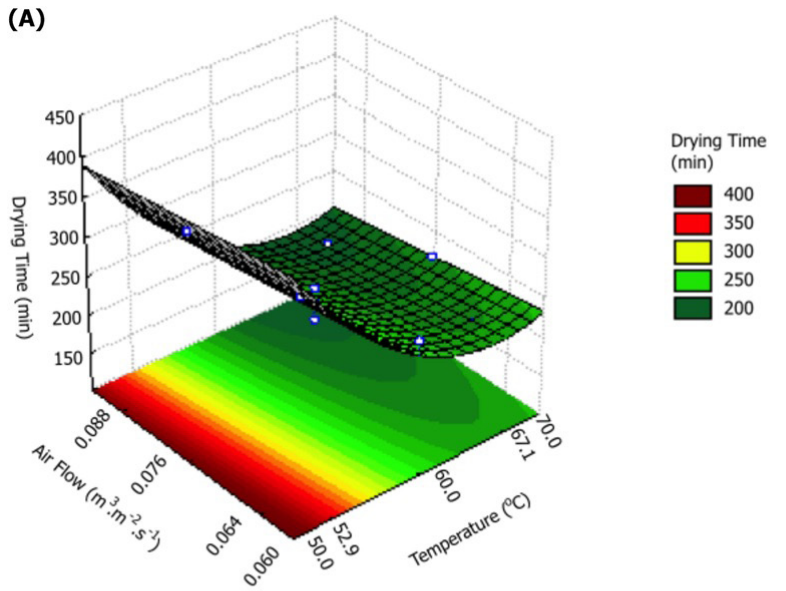

(B)

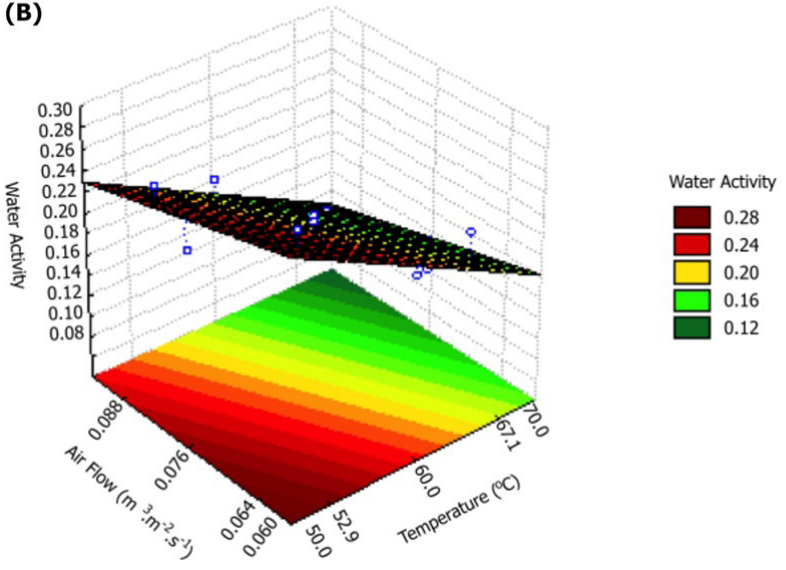

Figure 1. Drying time ( $\mathrm{min})(\mathrm{A})$; and water activity - Aw (B) of residual pulp of potato versus temperature $\left({ }^{\circ} \mathrm{C}\right)$ and drying air flow $\left(\mathrm{m}^{3} \mathrm{~m}^{-2} \mathrm{~s}^{-1}\right)$.

Temperature showed to be a factor inversely related to the drying time, since the increased temperature increases the diffusivity rate of water inside the product, with increased the water vapor saturation pressure of the material, also increasing the ability of air in dragging moisture from the surface of the product by increasing its saturation moisture content. The airflow influence, in turn, is given by the fact that its increase leads to a higher renewal rate of the drying air in contact with the product, i.e., the air becomes less saturated (Costa, 2007). The reduction of the drying time by increasing the temperature was verified by Kingsly et al. (2007) and García et al. (2008), while the effect of air flow or speed was confirmed by Tzempelikos et al. (2014).

However, no drying works with products similar to RPP were found in literature, since granular products are usually dried before the grinding process, as in the case of cereal flours, while starches of roots and tubers are usually dried in the sun (sour starch) or in other types of dryers, such as flash dryer (cassava starch) or drum dryers (banana flour). In relation to the Aw characteristic, values ranging from 0.106 to 0.274 were found. The higher the drying air temperature, the lower the response values (Figure 1B). As with the drying time, the Aw also showed that the airflow factor was not as influential to change the response as for temperature, although it has shown to be more relevant (Table 2).

When the water activity is less than 0.3 , there is risk of lipid oxidation (Bonazzi \& Dumoulin, 2011). However, although Aw values below this limit were reported, the concern with lipid oxidation was low due to the low content of this component in

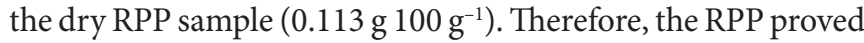
to be safe for storage and use with respect to water activity.

The $\mathrm{pH}$ values obtained varied significantly $(70 \%)$ among experiments, from 4.20 to 7.13 . It made us conclude that temperature and drying air flow conditions were crucial, as were for titratable acidity, which ranged from 0.711 to $2.625 \%$, a difference of $269 \%$. It was observed that the higher the air temperature, the lower the $\mathrm{pH}$ values (Figure $2 \mathrm{~A}$ ), indicating a more pronounced linear influence (Table 2). The area of maximum in the graph was observed, between temperatures of 50 and $60^{\circ} \mathrm{C}$ and air flows of 0.064 and $0.084 \mathrm{~m}^{3} \mathrm{~m}^{-2} \mathrm{~s}^{-1}$, where $\mathrm{pH}$ values were above 6.0. It is interesting to obtain a dry product with high $\mathrm{pH}$ for application in products such as baby food, desserts and ice creams, where a more neutral flavor is desirable.

Regarding airflow, there was a more pronounced quadratic effect compared to linear effect. As the values of this variable moved away from the center point (outliers), the $\mathrm{pH}$ values decreased.

The titratable acidity behavior showed similarities to that observed for $\mathrm{pH}$; however, area of minimum values was observed, which values were lower than $1.0 \%$, rather than area 
(A)

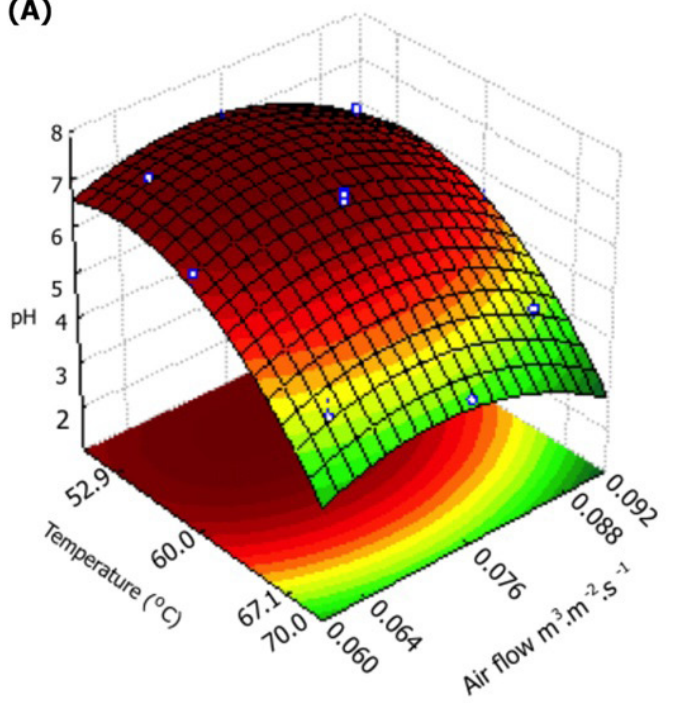

(B)

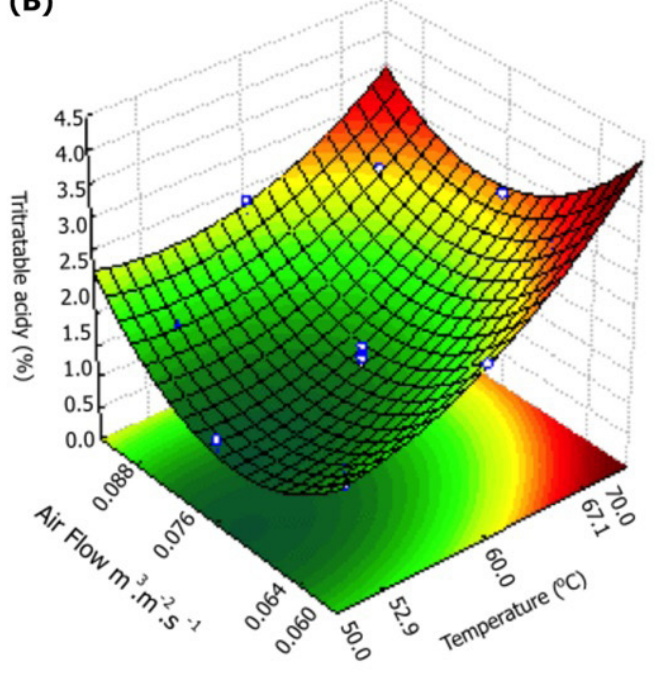

Figure 2. pH (A) and titratable acidity (\%) (B) of residual pulp of potato versus temperature $\left({ }^{\circ} \mathrm{C}\right)$ and drying air flow $\left(\mathrm{m}^{3} \mathrm{~m}^{-2} \mathrm{~s}^{-1}\right)$.

of maximum values (Figure 1D), which, however, showed a lower range (temperatures between 52.9 and $50^{\circ} \mathrm{C}$ and airflow from 0.064 to $\left.0.076 \mathrm{~m}^{3} \mathrm{~m}^{-2} \mathrm{~s}^{-1}\right)$. Linear temperature trend was also observed (Table 2), since the higher this magnitude, the higher the acidity values. As for the air flow, a more pronounced quadratic effect was observed, in which the lowest acidity values were found near the central point and, as it moved to the extreme of the graph, the acidity tended to be higher. Most titratable acidity values obtained ( 0.711 to $2.625 \%$ ) were above the maximum allowed by CNNPA Resolution No. 12 of 1978 (Brasil, 1978) for potato starch (2.0\%), but were all below levels allowed for sour cassava starch (5.0\%).

Dias et al. (2014) evaluated potato residual pulp dried at temperature of $60{ }^{\circ} \mathrm{C}$ of different cultivars and found $\mathrm{pH}$ values ranging from 6.15 to 8.48 , while in this work at the same temperature, $\mathrm{pH}$ ranged from 5.21 to 6.99 (Table 1). However, these authors obtained titratable acidity values for $\mathrm{cv}$. Atlantic lower than those of this study, with maximum value of $0.17 \%$.
This discrepancy could be because the fermentation processes of RPP started in the period between collection in industry and the onset of processing since it remained at room temperature and with high moisture content (about 90\%) for about $3 \mathrm{~h}$. Therefore, medium rich in starch and in the presence of excess water is prone to the action of naturally occurring microorganisms that produce amylolytic enzymes and initiate the formation of organic acids, mainly lactic acid, which increase the medium acidity (Montenegro et al., 2008).

Trombini et al. (2013) obtained $\mathrm{pH}$ values for cassava starch lower than those obtained by these authors (5.38) and intermediate titratable acidity of $1.36 \%$. All values obtained in this work were within ranges found for potato residual pulp, both for $\mathrm{pH}$ and for titratable acidity. This allows concluding that the drying conditions can significantly change the RPP quality, allowing obtaining different products with potential for different applications.

The lightness $\left(\mathrm{L}^{*}\right)$ values obtained in this study were very high, between 98.87 and 99.99 , which vary from black (0) to white (100), which allowed concluding that RPP samples were very clear, almost white. Comparing cassava starch samples of Freitas \& Leonel (2008), who obtained values of 92.21 for natural starch and 82.98 for extruded starch, a much clearer product was observed. The multiple regression analysis did not generate a statistically significant model for $\mathrm{L}^{*}$.

RPP samples showed neutral colour, close to zero in the chromatic scale, with low inclination to reddish and yellowish colour, even though not very prominent. The contour curves for these parameters were similar, showing area of minimum (Figure 3A). Chroma $\mathrm{a}^{*}$ showed this area at temperatures below $59^{\circ} \mathrm{C}$ and air flows near the center point $\left(0.072\right.$ to $\left.0.080 \mathrm{~m}^{3} \mathrm{~m}^{-2} \mathrm{~s}^{-1}\right)$, while chroma $b^{*}$ at temperatures below $53^{\circ} \mathrm{C}$ and air flow between 0.072 and $0.076 \mathrm{~m}^{3} \mathrm{~m}^{-2} \mathrm{~s}^{-1}$. The air temperature showed relevant linear trend for both models (Table 2), whereas air flow showed more pronounced quadratic influence, since as the airflow values deviate from the central point, responses would tend to show higher values. As the temperature increased, responses for chroma $\mathrm{a}^{*}$ and chroma $\mathrm{b}^{\star}$ also increased. It is suggested that the conditions of intermediate air flow (near $0.076 \mathrm{~m}^{3} \mathrm{~m}^{-2} \mathrm{~s}^{-1}$ ) and lower temperatures are used for obtaining whiter starches, more neutral in the chromatic scale or near $\mathrm{L}^{*}=1$, providing RPP high potential for application in food formulations with lighter appearance and the closest to white as possible (coconut milk, etc.), where minimal darkening is desirable.

By analyzing the WAI of RPP, it was observed that there was no gel formation, but rather the occurrence of a precipitate. This can be explained by the fact that the starch present in the dry residue was in its native state, since it was not pre-gelatinized or suffered other treatment but the drying process, which, therefore, was not a treatment sufficiently vigorous to expose hydrophilic groups present in the starch molecules. So, as there was no gelatinization, it could be observed that there was water absorption.

The WAI values ranged from 1.882 to $2.125 \mathrm{~g}$ gel ( $(\mathrm{g} \text { dry matter })^{-1}$, i.e., although the perceived influence of temperature and air flow was significant by the regression model (Table 2), the variation 
(A)

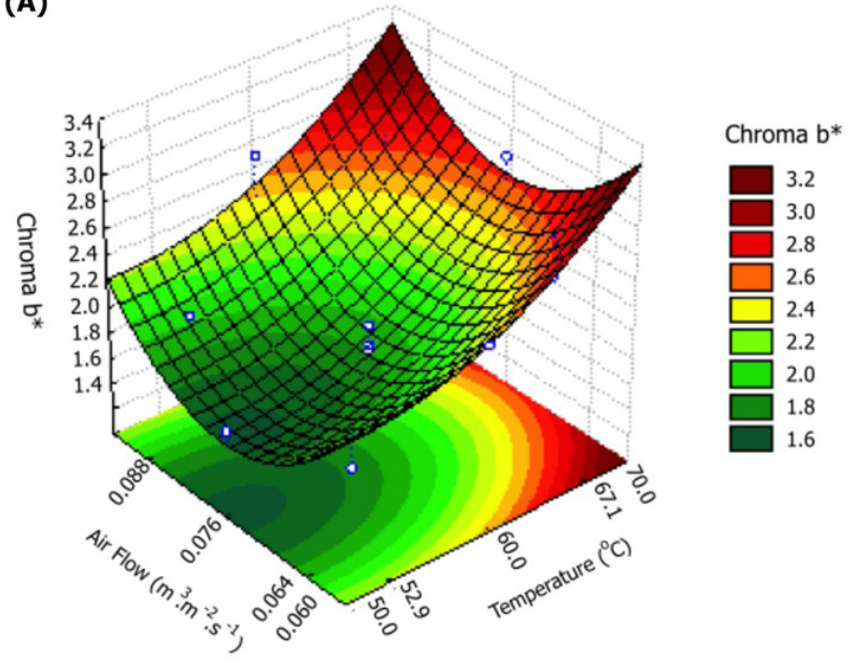

(B)

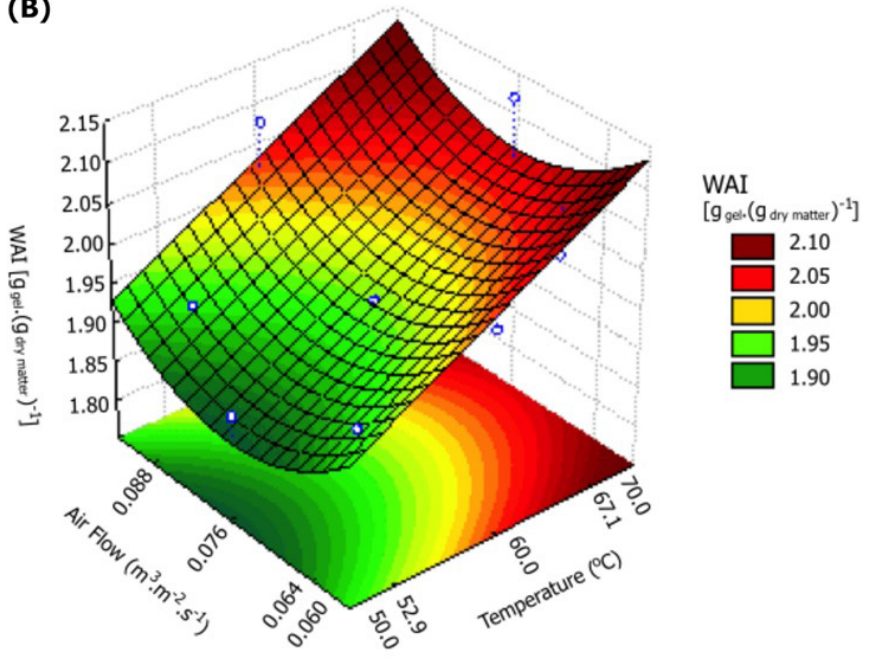

Figure 3. Chroma $b^{\star}(\mathrm{A})$ and water absorption index - WAI [g gel $\left.(\text { gdry matter })^{-1}\right]$ (B) of residual pulp of potato versus temperature $\left({ }^{\circ} \mathrm{C}\right)$ and drying air flow $\left(\mathrm{m}^{3} \mathrm{~m}^{-2} \mathrm{~s}^{-1}\right)$.

among values was small (11.4\%). The response surface graph (Figure 3B) showed WAI variation as a function of temperature and drying air flow, where area of minimum at temperatures below $53{ }^{\circ} \mathrm{C}$ and airflow around the central point were observed. Temperature had mostly linear influence for the range analyzed, and the higher the temperature, the higher the WAI values, which is in line with the trend observed by Ahmed et al. (2010) in sweet potato flour. This may be due to the action of temperature on starch molecules, exposing some hydrophilic groups by breaking glycosidic bonds, causing more water to be absorbed by the solid matrix of the pulp after drying.

The airflow factor showed quadratic influence on WAI, as occurred with chroma $\mathrm{a}^{*}$ and chroma $\mathrm{b}^{\star}$. In situations near the central point, the WAI value was lower and tended to increase to extreme values. Lower WAI values are important in products in which water absorption is undesirable, such as in certain types of biscuits, like wafers, since water absorbed from the environment may occur, softening the product, leading to loss of texture quality (crispness). RPP is possibly suitable to participate in the formulation of these types of products, and also in not instantaneous and baked products, where higher water absorption is desirable during the thermal process, since starch gelatinization affects the yield of the final product.

With increased air flow, there was a reduction and subsequent rise of chroma $\mathrm{a}^{*}$ and chroma $\mathrm{b}^{*}$, which were less clear or neutral, most likely due to the alteration of lightness, when higher gelatinization degree is achieved. WAI showed the same pattern of chroma $\mathrm{a}^{\star}$ and chroma $\mathrm{b}^{\star}$, i.e., in milder conditions, lower starch gelatinization occurred, with consequent decrease of its WAI. Trombini et al. (2013) found WAI values ranging from 5.8 and $8.8 \mathrm{~g}$ gel ( $\mathrm{g}$ dry matter) ${ }^{-1}$ for mixed flours of starch, cassava meal and extruded soybean meal. These values were higher than those obtained for RPP, which can be explained by the extrusion process, which involves high temperature and pressure, where starch granules undergo gelatinization and proteins are denatured. The gelatinized starch absorbs more water than in its natural state due to its structural and conformational changes, including in its hydrophilic / hydrophobic balance, contributing to increase or decrease WAI (Tacer-Caba et al., 2014). Similar WAI values compared to those of RPP were verified by Leonel et al. (2010), who evaluated mixtures of sour starch and linseed meal in different ratios, ranging from 2.08 to $2.28 \mathrm{~g}$ gel ( $\mathrm{g}$ dry matter $)^{-1}$. These authors also measured WAI after extrusion of mixtures, so that the values increased significantly, reaching up to $19.44 \mathrm{~g}$ gel ( $\mathrm{g}$ dry matter $)^{-1}$.

Both for water solubility index (WSI) and oil absorption capacity (OAC) of RPP, it was not possible to obtain significant regression models, since the results showed no statistically significant variations that could be explained by differences among experimental levels of temperature and drying air flow. The WSI

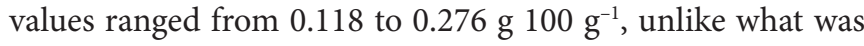
observed by Ahmed et al. (2010), who found a significant increase in WSI with increasing drying temperature of sweet potato flour pretreated with sodium bisulfate and calcium chloride; in the present work, the temperature did not influence this response.

Leonel et al. (2010), in a study with mixtures of sour cassava starch and soybean flour, obtained WSI values ranging from

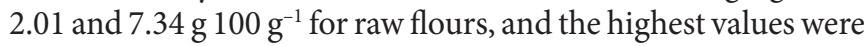
obtained in mixtures with higher proportion of soybean, which could be justified by the greater amount of soluble protein of this raw material. All these studies showed WSI values higher than those obtained for RPP, which proved to be practically insoluble in water at room temperature. This can be justified not only by the high content of native starch and low protein content, but also by the enzymatic modification that the product probably suffered after the release of granules in the water that washed potatoes and the action of native enzymes of the raw material. Flours and starches with low WSI values, as in the case of RPP could be applied to products which did not require instantaneous capacity in the preparation with water at room temperature, such as in products requiring cooking or baking like cakes, biscuits and bakery products in general.

The oil absorption capacity $(\mathrm{OAC})$ did not show large variations in their results, ranging from 1.52 to $1.57 \mathrm{~g}$ (g dry matter) $)^{-1}$, with variation coefficient of only $0.95 \%$. It was not possible to identify gelatinization of the solid material, but precipitation 
and mixing with soybean oil, where the latter has some of its contents entrapped in the product matrix. According to Ravi \& Susheelamma (2005), oil absorption is the ability to nonpolar sites of protein chains to entrap oil, so that the content and type of protein in the product determine the oil absorption capacity. Low OAC values were observed in RPP dried under different conditions, which may be explained by the fact that the starch present is in its native state and the low protein content of the material $\left(0.393 \mathrm{~g} 100 \mathrm{~g}^{-1}\right)$. By comparing these values with those obtained by Osundahunsi et al. (2003) for flours and starches from two sweet potato cultivars, perceived differences were striking. The lowest values obtained were $9 \mathrm{~g}(\mathrm{~g} \text { dry matter })^{-1}$ for sweet potato flour and $10 \mathrm{~g}$. ( $(\mathrm{g} \text { dry matter })^{-1}$ for native starch from sweet potato. The low OAC values, compared to the works above, also refer to the low protein content present in RPP, since this is the component that most affects this functional property. This can be an advantage in using RPP in products that would pass through frying processes since it would tend to decrease the oil absorption, making them healthier for human consumption.

Through the desirability test, RPP with higher $\mathrm{pH}$, and lower chroma $\mathrm{a}^{*}$, chorma $\mathrm{b}^{*}$ values and titratable acidity were obtained with air temperature of $60^{\circ} \mathrm{C}$ and air flow of $0.076 \mathrm{~m}^{3} \mathrm{~m}^{-2} \mathrm{~s}^{-1}$ (central point). Dry RPP obtained under these conditions showed high

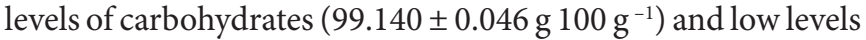

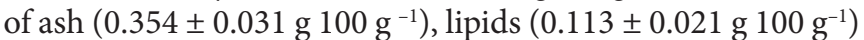

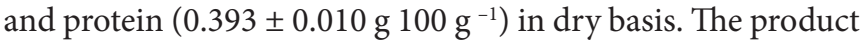
showed interesting nutritional potential for use in energy food such as cakes and biscuits due to its high carbohydrate content, which may be evidenced by the high energy value

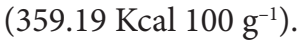

\section{Conclusion}

The drying air temperature strongly influenced the drying time, water activity, $\mathrm{pH}$, titratable acidity, chroma $\mathrm{a}^{\star}$ and chroma $\mathrm{b}^{\star}$ and water absorption index of dried potato residual pulp, showing linear influence on responses. The airflow showed minor relevance, with quadratic influence on responses $\mathrm{pH}$, titratable acidity, chroma $\mathrm{a}^{*}$ and chroma $\mathrm{b}^{*}$ and water absorption index. The characteristics of lightness $\left(\mathrm{L}^{\star}\right)$, water solubility index (WSI) and oil absorption capacity (OAC) were not affected by temperature and air flow. Therefore, the drying conditions can change the physicochemical and functional properties of RPP, which has potential for use in human food formulations, requiring further studies for their microbiological evaluation. Depending on the product to be applied, different temperature and air flow conditions may be recommended for the drying of potato residual pulp.

\section{References}

Ahmed, M., Sorifa, A. M., \& Eun, J. B. (2010). Effect of pretreatments and drying temperatures on sweet potato flour. International Journal of Food Science \& Technology, 45(2), 726-732. http://dx.doi. org/10.1111/j.1365-2621.2010.02191.x.

Anderson, R. A., Conway, H. F., Pfeifer, V. F., \& Griffin, E. L. Jr. (1969). Gelatinization of corn grits by roll-and extrusion-cooking. Cereal Science Today, 14(1), 130-135.
Association of Official Analytical Chemists - AOAC. (2012). Official methods of analysis of AOAC International (19th ed.). Washington: AOAC.

Bastos, G. M., Soares, M. S. Jr., Caliari, M., Pereira, A. L. A., Morais, C. C., \& Campos, M. R. H. (2016). Physical and sensory quality of gluten-free spaghetti processed from amaranth flour and potato pulp. LWT - Food Science and Technology, 65(1), 128-136. http:// dx.doi.org/doi:10.1016/j.lwt.2015.07.067.

Batista, J. E. R., Soares, M. S. Jr., Caliari, M., \& Araujo, M. M. (2016). Physical, microbiological and sensory quality of gluten-free biscuits of rice flour and potato pulp recovered from the effluent of fries processing. Journal of Food and Nutrition Research, 55(3), 101-107.

Bonazzi, C., \& Dumoulin, E. (2011). Quality changes in food materials as influenced by drying processes. In E. Tsotsas \& A. S. Mujumdar (Eds.), Modern drying technology: product quality and formulation, (Vol. 3, 1st ed., pp. 10-16). Weinheim: Wiley-VCH Verlag.

Brasil. Agência Nacional de Vigilância Sanitária. (1978). Resolução CNNPA no 12, de 24 de julho de 1978. Brasília: ANVISA. Retrieved from http://www.anvisa.gov.br/legis/resol/12_78.pdf.

Carvalho, W. T., Oliveira, T. F., Silva, F. A., Caliari, M., \& Soares, M. S. Jr. (2014). Drying kinetics of potato pulp waste. Ciência e Tecnologia de Alimentos, 34(1), 116-122. http://dx.doi.org/10.1590/S010120612014000100017.

Castilho, F., Fontanari, G. G., \& Batistuti, J. P. (2010). Evaluation of some fun7ctional properties of lupin sweet flour (Lupinus albus) and faba bean flour (Cajanus cajan (L) Millsp) and their utilization in cooked ham production. Food Science and Technology (Campinas.), 30(1), 68-75. http://dx.doi.org/10.1590/S0101-20612010005000007.

Costa, E. C. (2007). Secagem industrial. São Paulo: Editora Blücher. 196 p.

Dias, T. L., Oliveira, T. F., Caliari, M., \& Soares, M. S. Jr. (2013). Economic viability of a system for collecting and drying the pulp residual potato. Revista Verde de Agroecologia e Desenvolvimento Sustentável, 8(2), 52-57.

Dias, T. L., Oliveira, T. F., Campos, M. R. H., \& Soares, M. S. Jr. (2014). Utilization of residual pulp of potato in snacks as prospect of reducing environmental impact. Revista Brasileira de Engenharia Agrícola e Ambiental, 18(2), 225-230. http://dx.doi.org/10.1590/ S1415-43662014000200014.

Freitas, T. S., \& Leonel, M. (2008). Resistant starch in cassava on different extrusion operational conditions. Alimentos e Nutrição, 19(2), 183-190.

García, C. F., Moyano, P. C., \& Pedreschi, F. (2008). Enthalpyentropy compensation for water loss of vegetable tissues during air drying. Drying Technology, 26(12), 1563-1569. http://dx.doi. org/10.1080/07373930802466997.

Instituto Adolfo Lutz. (2008). Physicochemical methods for food analysis (4th ed.). São Paulo: Instituto Adolfo Lutz. 1020 p.

Kingsly, R. P., Goyal, R. K., Manikantan, M. R., \& Ilyas, S. M. (2007). Effects of pretreatments and drying air temperature on drying behaviour of peach slice. International Journal of Food Science \& Technology, 42(1), 65-69. http://dx.doi.org/10.1111/j.1365-2621.2006.01210.x.

Leonel, M., Martins, J. C., \& Mischan, M. M. (2010). Production of extruded snacks from cassava starch and orange fiber. Ciência Rural, 40(6), 1418-1423. http://dx.doi.org/10.1590/S0103-84782010005000092.

Montenegro, F. M., Gomes-Ruffi, C. R., Vicente, C. A., Collares-Queiroz, F. P., \& Steel, C. J. (2008). Fermented cassava starch biscuits enriched with soluble and insoluble fibers. Food Science and Technology (Campinas.), 28(Suppl.), 184-191. http://dx.doi.org/10.1590/S010120612008000500029. 
Osundahunsi, O. F., Fagbemi, T. N., Kesselman, E., \& Shimoni, E. (2003). Comparison of the physicochemical properties and pasting characteristics of flour and starch from red and white sweet potato cultivars. Journal of Agricultural and Food Chemistry, 51(8), 22322236. http://dx.doi.org/10.1021/jf0260139. PMid:12670162.

Paucar-Menacho, L. M., Barreto, P. A. A., Mazal, G., Fakhouri, F. M., Steel, C. J., \& Collares-Queiroz, F. P. (2008). Development of functional fresh food adding soy protein isolate and polidextrose using paprika as coloring agent. Food Science and Technology (Campinas.), 28(4), 767-778. http://dx.doi.org/10.1590/S0101-20612008000400002.

Ravi, R., \& Susheelamma, N. S. (2005). Simultaneous optimization of a multy-response system by desirability function analysis of boondi making: A case study. Journal of Food Science, 70(8), 539-547. http:// dx.doi.org/10.1111/j.1365-2621.2005.tb11531.x.

Silva, F. A., Marsaioli, A. Jr, Maximo, G. J., Silva, M. A. A. P., \& Gonçalves, L. A. G. (2006). Microwave assisted drying of macadamia nuts. Journal of Food Engineering, 77(3), 550-558. http://dx.doi.org/10.1016/j. jfoodeng.2005.06.068.

Tacer-Caba, Z., Nilufer-Erdil, D., Boyacioglu, M. H., \& Ng, P. K. (2014). Evaluating the effects of replacing amylose powder and Concord grape extract on physicochemical properties of wheat flour extrudates produced at different temperatures. Food Chemistry, 157(15), 476-484. http://dx.doi.org/10.1016/j.foodchem.2014.02.064. PMid:24679807.
Trombini, F. R. M., Leonel, M., \& Mischan, M. M. (2013). Development of extruded snacks from blends of soya flour, cassava starch and bran. Ciência Rural, 43(1), 178-184. http://dx.doi.org/10.1590/ S0103-84782012005000123.

Tzempelikos, D. A., Vouros, A. P., Bardakas, A. V., Filos, A. E., \& Margaris, D. P. (2014). Case studies on the effect of the air drying conditions on the convective drying of quinces. Case Studies in Thermal Engineering, 3(7), 79-85. http://dx.doi.org/10.1016/j. csite.2014.05.001.

Vega-Gálvez, A., Ah-Henb, K., Chacanaa, M., Vergaraa, J., MartínezMonzóc, J., García-Segoviac, P., Lemus-Mondacaa, R., \& Di Scalae, K. (2012). Effect of temperature and air velocity on drying kinetics, antioxidant capacity, total phenolic content, colour, texture and microstructure of apple (var. Granny Smith) slices. Food Chemistry, 132(1), 51-59. http://dx.doi.org/10.1016/j.foodchem.2011.10.029. PMid:26434262.

Wang, R., Wang, Y., Ma, G., He, Y., \& Zhao, Y. (2009). Efficiency of porous burnt-coke carrier on treatment of potato starch wastewater with an anaerobic-aerobic bioreactor. Chemical Engineering Journal, 148(1), 35-40. http://dx.doi.org/10.1016/j.cej.2008.07.028.

Waszczynskyj, N., Rao, C. S., \& Silva, R. S. F. (1981). Extraction of proteins from wheat bran: application of carbohydrates. Cereal Chemistry, 58(4), 264-266. 